Portland State University

PDXScholar

\title{
Lifetime reproductive Success of Female Eastern Kingbirds (Tyrannus Tyrannus): Influence of Lifespan, Nest Predation and Body Size
}

Michael T. Murphy

Portland State University, murphym@pdx.edu

Follow this and additional works at: https://pdxscholar.library.pdx.edu/bio_fac

Part of the Biology Commons, Ornithology Commons, and the Population Biology Commons Let us know how access to this document benefits you.

\section{Citation Details}

Murphy, Michael T., "Lifetime reproductive Success of Female Eastern Kingbirds (Tyrannus Tyrannus): Influence of Lifespan, Nest Predation and Body Size" (2007). Biology Faculty Publications and Presentations. 71.

https://pdxscholar.library.pdx.edu/bio_fac/71

This Article is brought to you for free and open access. It has been accepted for inclusion in Biology Faculty Publications and Presentations by an authorized administrator of PDXScholar. Please contact us if we can make this document more accessible: pdxscholar@pdx.edu. 


\title{
LIFETIME REPRODUCTIVE SUCCESS OF FEMALE EASTERN KINGBIRDS (TYRANNUS TYRANNUS): INFLUENCE OF LIFESPAN, NEST PREDATION, AND BODY SIZE
}

\author{
Michael T. Murphy ${ }^{1}$ \\ Department of Biology, Portland State University, P.O. Box 751, Portland, Oregon 97207, USA
}

\begin{abstract}
Aвstract. - I report on the lifetime reproductive success (LRS) of female Eastern Kingbirds (Tyrannus tyrannus) in central New York. I investigated the major correlates of LRS and specifically tested the hypothesis that small body size yields reproductive benefits. Lifetime reproductive success varied widely: $15-20 \%$ of females failed to fledge young over their life, whereas $50 \%$ of young were fledged by $20 \%$ of females. Female lifespan varied between one and eight years, and females that died after one breeding season tended to be smaller-bodied than long-lived females ( $\geq 2$ seasons). I therefore conducted analyses of LRS for the entire sample and for longerlived females separately. As in other species, lifespan was the strongest predictor of LRS, followed by the proportion of eggs laid that resulted in fledged young (P). Lifetime reproductive success varied positively with clutch size and, as predicted, inversely with body size (i.e., tarsus length) of females. However, variance partitioning indicated that most variation in LRS was attributable to the effects of lifespan and $\mathrm{P}$, but that a substantial negative covariance existed between lifespan and $\mathrm{P}$. The latter result was consistent with experimental evidence of a cost of reproduction in Eastern Kingbirds. Analysis of the correlates of lifespan, P, and clutch size showed that over a female's lifetime, (1) the longest-lived birds fledged an intermediate proportion of the eggs that they laid, (2) the most productive birds were of intermediate wing length, and (3) females with small tarsi produced the largest clutches and lost the fewest nests to predators. Hence, although lifespan was the dominant influence on LRS, negative effects of large female size appeared to be expressed through the influence of body size on other demographic parameters that contribute to LRS. Received 20 July 2005, accepted 11 September 2006.
\end{abstract}

Key words: clutch size, cohort effect, Eastern Kingbird, fledging success, reproductive trade-offs, Tyrannus tyrannus.

Éxito Reproductivo Completo de Vida de Hembras de Tyrannus tyrannus: Influencia de la Duración de la Vida, la Depredación de Nidos y el Tamaño Corporal

Resumen.-En este estudio brindo información sobre el éxito reproductivo completo de vida (ERC) de hembras de Tyrannus tyrannus en el centro de Nueva York. Investigué los principales correlatos del ERC y probé específicamente la hipótesis de que un tamaño corporal pequeño proporciona beneficios. El éxito reproductivo total varió mucho: el $15-20 \%$ de las hembras no emplumaron polluelos durante su vida, mientras que el $50 \%$ de los polluelos fueron emplumados por el $20 \%$ de las hembras. Las hembras vivieron entre uno y ocho años; las hembras que murieron después de una época reproductiva tendieron a ser más pequeñas que las que vivieron más tiempo (2 épocas reproductivas). Por lo tanto, los análisis de ERC para toda la muestra y para las hembras que vivieron más tiempo fueron realizados

\footnotetext{
${ }^{1}$ E-mail: murphym@pdx.edu
} 
por separado. Como se encontró para otras especies, la duración de la vida fue la variable que mejor predijo el ERC, seguida por la proporción de huevos puestos que resultaron en polluelos emplumados $(\mathrm{P})$. El éxito reproductivo completo varió positivamente con el tamaño de la puesta, y como predicho, de manera inversa con el tamaño corporal (i.e., largo del tarso) de las hembras. Sin embargo, la partición de la varianza indicó que la mayor parte de la variación en el ERC estuvo dada por los efectos de la duración de la vida y $\mathrm{P}$, pero que existió una covarianza negativa substancial entre la duración de la vida y P. Este último resultado fue consistente con evidencia experimental del costo reproductivo en T. tyrannus. Los análisis de los correlatos de la duración de la vida, P y el tamaño de la puesta mostraron que a lo largo de la vida de una hembra, (1) las aves que vivieron más tiempo emplumaron una proporción intermedia de los huevos puestos, (2) las aves más productivas tuvieron alas de largo intermedio y (3) las hembras con tarsos cortos produjeron las puestas más grandes y perdieron el menor número de nidos por depredación. Por lo tanto, a pesar de que la duración de la vida influenció fuertemente el ERC, los efectos negativos de hembras de gran tamaño parecen expresarse a través de la influencia del tamaño corporal sobre otros parámetros demográficos que contribuyen al ERC.

LONG-TERM STUDIES OF vertebrates have shown that relatively few adults contribute young to future generations and that variation of lifetime reproductive success (LRS) is most strongly associated with lifespan, followed often by the frequency of reproductive failure (Clutton-Brock 1988, Newton 1989, Korpimäki 1992, Coltman et al. 1999). Among birds, nest predators account for most failures in small- to medium-sized species (Ricklefs 1969, Martin 1993) and, in the few species that have been examined, nest predation is an important contributor to variation in LRS (Hötker 1989; Wiklund 1995, 1996; Ekman et al. 1999).

Variation in LRS also often emerges as a cohort or year effect (Rose et al. 1998, Reid et al. 2003; but see Krüger and Lindström 2001, Hansson et al. 2004), and individuals born or hatched during good years may express that advantage throughout their life (the "silver spoon effect"; Grafen 1988). For instance, male Tengmalm's Owls (Aegolius funereus) hatched during the growth phase of vole (Microtus spp. and Clethrionomys spp.) population cycles had higher LRS than counterparts hatched during a decline phase (Korpimäki 1992). Natal breeding conditions (as determined by weather) for Red-billed Choughs (Pyrrhocorax pyrrhocorax) ultimately determined much of LRS of recruits (Reid et al. 2003). Events that vary among years and affect the entire population may also have important influences on LRS. Most mortality of adult passerines seems to occur outside of the breeding season (but see Brown and Brown
1998) and, for migrants, perhaps during migration (Butler 2000, Sillett and Holmes 2002) or at wintering locations (Jones 1987).

At the same time, individuals hatched or born in the same year may differ in LRS, because of inherent individual differences associated with morphology (Bryant 1988) or reproductive traits such as clutch size (Korpimäki 1992) or breeding date (Visser and Verboven 1999). Given otherwise similar conditions, some parents can shunt a greater share of daily energy intake to reproduction without compromising survival, and individual optimization of effort may account for much population-level variation in productivity (Pettifor 1993). But why can some birds devote more energy to reproduction than others and, for example, lay larger clutches? Small passerines are believed to be income breeders (Drent and Daan 1980, Meijer and Drent 1999), and assuming trade-offs between reproduction and maintenance of somatic tissues, individuals with low metabolic demands should have advantages. Downhower (1976) proposed that low maintenance costs associated with small body size yield reproductive benefits (see also Price 1984, Murphy 1986a), but other studies suggest energetic (Bryant and Westerterp 1982, 1983) and social (Garnett 1981, Langston et al. 1990) advantages of large size. On the whole, however, the degree to which body size contributes to offspring production and variation in LRS is poorly known; this is probably attributable, in part, to the subtle effect of body size on LRS compared with variation associated with 
lifespan, frequency of reproductive failure, and cohort or year effects.

Eastern Kingbirds (Tyrannus tyrannus; hereafter "kingbirds") are Nearctic-Neotropical migrants that form socially monogamous pair bonds and show high site-fidelity (Murphy 1996). Kingbirds attempt to raise one brood of 3-4 young year ${ }^{-1}$, but nest predators destroy $\geq 50 \%$ of nests. Rates of nest loss show high annual variation (Murphy 2000), and males devote much time to predator vigilance (Woodard and Murphy 1999), whereas females take sole responsibility for nest building, incubation, and brooding of young, and make nearly $70 \%$ of trips to feed young (Woodard and Murphy 1999).

Here, I report an analysis of LRS of female kingbirds on the basis of 13 years of data from a population located in central New York. For comparative purposes, I describe variation in individual LRS at the population level and then test for possible year effects on LRS, and for reproductive and morphological correlates of variation of LRS. I expected lifespan and nesting success to be major determinants of LRS, but given evidence of costs of reproduction (Murphy 2000), I predicted also that small females would have an energetic advantage and that LRS would vary inversely with body size.

\section{Methods}

Field procedures. - I conducted research in the Charlotte Valley in Delaware and Otsego counties in New York $\left(42^{\circ} 78^{\prime} \mathrm{N}, 74^{\circ} 53^{\prime} \mathrm{W}\right)$ from 1989 through 2001. Charlotte Creek flowed through the center of the study area, and kingbirds nested along the riparian corridor and surrounding floodplain and upland habitats. Kingbirds (35-45 g) foraged by capturing flying insects in open habitats, and females built opencup nests in trees (3-5 m above ground). Nests were conspicuous and easily found, and pairs rarely escaped detection.

Breeding statistics used in the present study included breeding date (= date of first egg), clutch size (eggs per nest), and number of young to fledge (young alive 13 days after hatching). Nests were checked regularly, and if failures occurred, I located replacement nests and collected identical data to determine seasonal productivity (young produced in either initial or replacement nests). Because of the difficulty of capturing adults without dependent young (and concerns over nest abandonment), I captured parents at the nest (with mist nets) mainly during the second half of the nestling period. Upon capture, I measured body mass, wing chord, and bill and tarsometatarsus [= tarsus] lengths, and individually marked birds with one numbered federal aluminum band and three colored plastic leg bands (Murphy 2000, 2001). Female morphological traits were all significantly repeatable among years (Murphy 2004); hence, I used measurements made on the first capture occasion in all analyses. Returns were based on visual observations and recaptures of banded birds.

Lifetime reproductive success: Empirical and modeled estimates. - I obtained longevity records for 159 females, 155 of which were banded before 1999. That year was significant because resighting probability $(P)$ is high in this population $(P>0.85$; Murphy 1996) and no bird reappeared after an absence of two years. Thus, any banded bird missing in 2001 was almost certainly dead. None of the females banded in 1999 was seen in 2001, but five other banded females were present: three, one, and one from 1995, 1997, and 1998, respectively. All these birds were included in the analyses, the effect of which is to make my estimates of the variability of LRS conservative. The year of capture was treated as age one, which no doubt underestimated age for some birds, especially those from the first years of the study. However, as shown below, average LRS of birds from the first year was the highest of any year, and the first two years showed two of the six highest average estimates of LRS. Hence, my use of the year of banding as age one is unlikely to have seriously affected estimated LRS (see also Payne 1989). Every female that I observed attempted to breed in every year that I knew the female was present, but occasionally a female was not observed in one year and reappeared in the next. I assumed that the female attempted to breed outside the immediate study area in the year that I missed it and that its dispersal back into the study area was attributable to a failure during the year that the female was away, because females are most likely to disperse after a failure (Murphy 1996). I also assumed that all females began to breed in their first year. Lifetime reproductive success might potentially decline with age at first reproduction (assuming constant probability of adult 
survival) if some females delay breeding, but in species in which this parameter varies, others have shown that LRS is correlated strongly with breeding lifespan and that variation in the age of first breeding did not affect LRS (Korpimäki 1992, Reid et al. 2003; but see Oli et al. 2002).

High adult site-fidelity and resighting probability lend confidence to the calculations of LRS for banded birds, but, because banding was restricted to the second half of the nestling period, the population-level estimates of the mean and variance of LRS omitted unbanded birds that failed before capture. I attempted to resolve this potentially serious omission by modeling LRS for a hypothetical population to compare with the banded population. The model (developed using STELLA, version 8; ISEE Systems, Lebanon, New Hampshire) was based on empirically derived estimates of the Charlotte Valley kingbird population's (1) mean clutch size (mean \pm SD; first nests: $3.2 \pm 0.57$ eggs, $n=635$; replacement clutches: $2.9 \pm 0.52$ eggs, $n=$ $215),(2)$ frequency of hatching failure $(7 \%$ and $14 \%$ of eggs in first and replacement clutches, respectively), (3) rates of nestling starvation $(5.7 \%$ and $2.5 \%$ of nestlings in first and replacement clutches, respectively), (4) probability of whole-nest failure (55\% and $44 \%$, respectively, of first and replacement clutches), (5) probability of nest replacement (0.67), and (6) probability of adult survival (0.625). Females were assumed to breed every year and raise one brood year ${ }^{-1}$ but to replace most failed first nests. The model began with the laying of an initial clutch (drawn from a normal distribution with mean \pm SD appropriate to first clutches). Partial and whole nest losses were generated through Monte Carlo simulations using the probabilities given above. If the first nest failed, females renested with a probability of 0.67 , and the same contingencies applied for the renesting attempt (but with statistics appropriate for replacement clutches). Annual productivity was the number of young fledged from the first nest (if successful) or from the replacement nest (if first nest failed and she replaced it), or (if both failed) zero. I iterated the model until each female died (maximum lifespan $=$ the population's observed maximum age) to simulate 1,000 kingbird lives.

Data analyses. - I used 136 females for whom complete morphological and breeding data were available to identify correlates of LRS (= number of young fledged over a lifetime).
Composite measures of size generated by multivariate techniques (e.g., principal component analysis [PCA]) are generally believed to provide better estimates of size than individual morphological characters (Freeman and Jackson 1990). However, body-composition analysis of another kingbird population showed that individual morphological characters predicted total muscle mass as well as or better than a size axis generated by PCA (M. T. Murphy unpubl. data) and, therefore, I used bill and tarsus lengths and wing chord as estimates of female size. Of these, tarsus length is generally viewed as the best single estimate of body size (Rising and Somers 1989, Senar and Pascual 1997, Nooker et al. 2005).

Variables that potentially generated variation in LRS included breeding date, clutch size, proportion of eggs laid that resulted in fledged young, and body size. Breeding date and clutch size are repeatable female traits (Murphy 2004), and I calculated both as the mean value for all first clutches of the season over a bird's lifetime. I included breeding date and clutch size because early breeders presumably had more time to lay replacement clutches to offset initial nest failures, and large clutch size led potentially to more fledglings and a higher LRS (e.g., Korpimäki 1992). The proportion of eggs laid that resulted in fledged young (used synonymously with "fledging success") was calculated for the last nest tended by a female in each year of her life. Nest failures were categorized as being from predation, starvation, weather, abandonment, poor nest construction, parental death, or unknown causes.

Natal return rate was low (3-4\%; Murphy 2000) and, thus, I could not test for cohort effects because most females were of uncertain age when first captured (though most were probably females in their first breeding season; Murphy 2004). Nonetheless, an effect of year of capture on LRS was a possibility and, indeed, I detected an association between year of banding and LRS (using regression analysis). Thus, analyses of the correlates of LRS were based on the residual LRS obtained from the regression of LRS against year (see below).

The brood sizes of some females were manipulated as part of separate experiments for another study (Murphy 2000). Of the females included in the current analyses, 9 and 37 were forced once to raise a brood reduced or 
enlarged, respectively, by 1 (rarely 2) young beginning when the young were 1-3 days old. Nestling starvation was not common in either manipulated or natural broods, and manipulation had no influence on the probability of whole-nest failure (Murphy 2000). To characterize natural variation in LRS, I therefore allowed for natural losses, but assumed that no young were moved into or out of nests (e.g., three fledglings assigned to a female that laid a clutch of three eggs but raised an enlarged brood of four young). Females that were forced to raise broods of five had a lower probability of returning in the year following brood enlargement (Murphy 2000); therefore, to account for this possible effect on lifetime success, I included a variable (BrSize5) in my analyses.

I used STATISTIX (Analytical Software, Tallahassee, Florida) for all statistical tests. Neither lifespan nor LRS were normally distributed, but they exhibited a strong linear relationship $(r=0.831, P<0.001, n=136)$. After removing the effects of lifespan, residual LRS was normally distributed (KomogorovSmirnov test, $Z=1.191, P=0.117)$. I therefore used multiple regression analyses to examine the relationship between LRS and predictor variables. All variables were $z$-transformed (i.e., mean of zero and standard deviation of one) before analyses and, therefore, the regression coefficients that I report are standardized betas ( $\beta)$. I used the "Best Subsets Regression" option in STATISTIX to generate all combinations of the predictor variables to select the model that provided the best fit to the data. The criteria for selection of the best model were (1) that it had the smallest difference between the number of variables in the model and Mallow's Cp (STATISTIX), (2) that it had the highest adjusted $R^{2}$, and (3) that all variables in the model contributed significantly $(P \leq 0.05$, except if noted). I then used Brown's (1988) method of partitioning variances to quantify the contributions to variance of LRS by all variables that were included in the multiple regressions. Brown's (1988) approach accounts for the covariances among variables and quantifies the independent contribution of each variable when all other variables are held constant at their mean values, and identifies potentially important covariances among main variables. Proportions were arcsine transformed, and $P$ values were based on type III sums of squares.
Results are reported as means $\pm \mathrm{SD}$, unless otherwise noted.

\section{Results}

Lifespan and lifetime reproductive success.The empirical results presented below were based on 350 individual breeding attempts by 159 different females. The average female reproductive lifespan was $2.20 \pm 1.65$ years (95\% confidence interval [CI]: 1.94-2.46, range: $1-8$ years, $n=159$ ) and over that time, average LRS was $4.40 \pm 3.56$ young $(95 \% \mathrm{CI}$ : 3.84-4.95, range: $0-19, n=159)$. Mean lifespan of the simulated population was slightly longer $(2.60 \pm 1.78$ years, $95 \%$ CI: $2.48-2.70)$, but LRS was similar and did not differ statistically from the Charlotte Valley population (4.80 \pm 4.15 young, 95\% CI: 4.54-5.05, range: 0-25). Simulated females showed a tendency toward either high or low success, whereas LRS of banded females tended to be better represented in the range of one to five young (though the proportion of females to produce three young was identical; Fig. 1). The distribution of LRS for observed and simulated populations did not differ (Kolmogorov-Smirnoff test, $P=$ 0.477). The greatest discrepancy between the observed and simulated population was that, as suspected, the field data tended to underrepresent females with zero LRS $(10.8 \%$ vs. $16.9 \%)$, but observed females also tended to successfully fledge more broods of two.

Females exhibited distinct peaks in natural LRS at 0 and 3 young (Fig. 1), which corresponded mostly to a single year of failed or successful breeding. Life reproductive success then

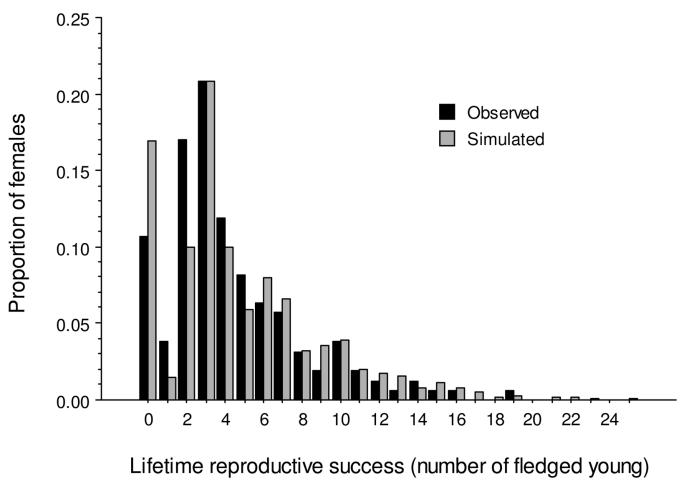

FIg. 1. Variation in lifetime reproductive success of female Eastern Kingbirds. 
declined monotonically to a maximum of 19 young. Only $10.1 \%$ and $13.5 \%$ of observed and simulated females fledged $\geq 10$ young, respectively, and LRS exhibited large differences among females. The disparities in individual LRS were highlighted by the fact that $50 \%$ of young were produced by $21.5 \%$ of the females (20.5\% for simulated females), and the top $10 \%$ of the most productive females produced $29.9 \%$ of all young (29.6\% for simulated females).

Year effects.-Lifetime reproductive success exhibited a significant third-order polynomial relationship with year of capture $(P \leq 0.045$ for all terms; $R^{2}=7.3 \%$ ). Lifetime reproductive success declined over the first three years of the study, climbed between 1993 and 1995, and then declined to the end of the study (Fig. 2). Although variation of seasonal fecundity (mean number of young produced female ${ }^{-1}$ year $\left.{ }^{-1}\right)$ and annual failure rate were high (Murphy 2000, 2001), neither varied in a regular manner with year $(P>0.35$ for all linear, second- and thirdorder terms for year). Lifespan also exhibited a significant third-order polynomial relationship with the year that the bird entered the study $(P \leq 0.039$ for the linear and second- and third-order terms for year), and LRS was highly correlated with lifespan $(r=0.831, P<0.001, n=$ 136). Because of the temporal variation in LRS, I removed the effect of year of entry into the banded population and used the residuals in all further analyses of LRS.

Predictors of variation of life reproductive success. - Just under half (45\%) of the 136 females bred for one year, whereas lifespan for the remaining individuals averaged $3.30 \pm 1.63$ years $(n=79)$. Comparisons of body size of short-lived (1 year) and longer-lived ( $\geq 2$ years) females on the date of initial capture showed

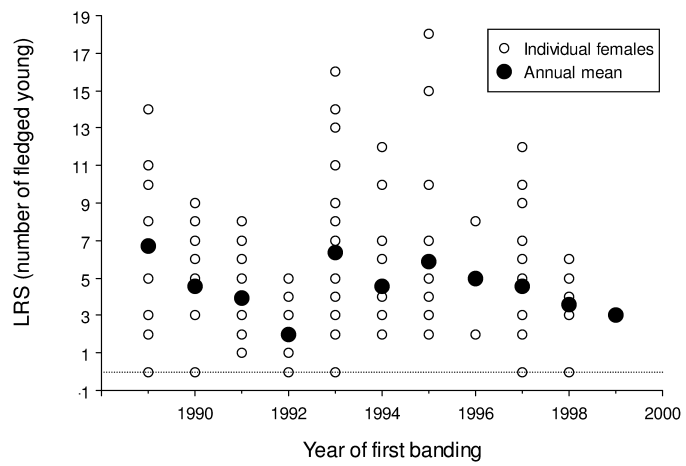

FIG. 2. Lifetime reproductive success of female Eastern Kingbirds plotted against their year of banding.

that short-lived females had shorter bills ( $t=$ 1.984, $P=0.049)$ and tended to have shorter wing chords $(t=1.861, P=0.065)$ and tarsi $(t=$ $1.677, P=0.096)$. Fisher's method of combining probabilities (Sokal and Rohlf 1981) confirmed that, on average, short-lived females tended to be smaller birds $\left(\chi^{2}=16.185, \mathrm{df}=6, P=0.021\right)$.

Given the latter difference, I analyzed LRS for the entire sample $(n=136)$ and then for the longer-lived females $(n=79)$ separately. For both samples, LRS increased with lifespan, fledging success, and clutch size (Table 1). For females of all ages, LRS exhibited a marginally significant inverse relationship with wing chord $(P=0.054)$. Analyses accounted for $82-84 \%$ of the variation of LRS, and BrSize5 had no influence on the results of either analysis $(P \geq$ 0.75). Examination of residual LRS against wing chord (after removing the effects of the three other variables) revealed one strong outlier (more than six standard deviations below the predicted value). I therefore repeated the

TABLE 1. Results of the stepwise multiple-regression analyses of lifetime reproductive success of female Eastern Kingbirds in central New York. Standardized regression coefficients $(\beta)$ are reported ( $P$ in parentheses).

\begin{tabular}{lccccc}
\hline \hline & \multicolumn{2}{c}{ Females of all ages } & & \multicolumn{2}{c}{ Females $\geq 2$ years of age } \\
\cline { 2 - 3 } \cline { 6 - 6 } Variable & $(n=136)$ & $(n=135)$ & & $(n=79)$ & $(n=78)$ \\
\hline Lifespan & $0.860(0.000)$ & $0.930(0.000)$ & & $0.792(0.000)$ & $0.899(0.000)$ \\
Proportion fledge & $0.457(0.000)$ & $0.476(0.000)$ & & $0.780(0.000)$ & $0.788(0.000)$ \\
Clutch size & $0.106(0.003)$ & $0.105(0.000)$ & & $0.141(0.009)$ & $0.152(0.000)$ \\
Wing chord & $-0.068(0.054)$ & - & - & - & $-0.090(0.027)$ \\
Tarsus & - & $-0.089(0.003)$ & & - & 0.918 \\
$r^{2}$ & 0.836 & 0.893 & & 0.821 & \\
\hline
\end{tabular}


analyses without this female, and the explained variation increased to $89-92 \%$. Lifespan, fledging success, and clutch size were again included in the models, with a greater contribution from lifespan (Table 1). However, the greatest difference emerged in the relationship of LRS to morphology. Tarsus length emerged as a significant predictor of LRS within the entire sample and subset of older females (Table 1), which suggests higher LRS among females with short tarsi. Variable BrSize5 had no influence on LRS $(P \geq 0.154)$ and, among older females, clutch size tended to be negatively associated with tarsus length in both females that never raised broods of five $(\beta=-0.371, r=-0.338, P=0.014, n=70)$ and those that did $(\beta=-0.328, r=-0.528, P=$ $0.144, n=9$; difference in slope between groups: $F=0.03, P=0.873$ ).

Partitioning of the variance in LRS (Brown 1988) into components explained by lifespan (P), proportion of eggs to yield fledged young $(\mathrm{P})$, clutch size $(\mathrm{C})$, and tarsus length $(\mathrm{T})$ for the full sample (analyses conducted without the outlier) indicated that lifespan accounted for $90.7 \%$ of the variance in LRS when $\mathrm{P}, \mathrm{C}$, and $\mathrm{T}$ were held constant at their mean values. Corresponding values for $\mathrm{P}(39.2 \%)$ and the covariance term for $\mathrm{L}$ and $\mathrm{P}(-37.0 \%$; Table 2$)$ were nearly equal, and the latter suggested that females who fledged a lower proportion of eggs lived longer. Variance of LRS associated with clutch size was low (3.5\%), and $\sim 10 \%$ of the amount associated with both P and LP. Variance in LRS linked uniquely with $\mathrm{T}$ was negligible (Table 2). Within the older females, variance of LRS showed a reduced dependence on L but an increased influence of $\mathrm{P}$ (Table 2). The negative covariance term between $\mathrm{L}$ and $\mathrm{P}$ decreased $(-20.0 \%)$, but again suggested that low fledging success and L were positively associated (Table 2). The variance in LRS associated with C increased slightly to $5.5 \%$, but that associated with $\mathrm{T}$ remained near zero (Table 2).

Lifetime reproductive success depended most heavily on lifespan and fledging success, followed distantly by clutch size. Therefore, I conducted additional analyses to identify correlates of all three variables (Poisson regression for lifespan and all subsets, and multiple regression for fledging success and clutch size). In addition, graphical analyses suggested a polynomial relationship between lifespan and fledging success and, therefore, I examined lifespan in relation to individual morphological characters, breeding date, clutch size, and fledging success (and its quadratic term) after controlling for year effects (see above). Analysis of the entire sample, and then of the older females separately, suggested that the longest-lived females exhibited intermediate fledging success, and within the entire sample, long life tended to be associated with early breeding (Table 3 ).

Nest predators accounted for most of the nest failure ( $71 \%, n=107$ nests), followed by complete brood starvation (5.6\%), abandonment $(5.6 \%)$, weather $(4.7 \%)$, and other causes (total $=13.0 \%$ ). A second-order polynomial relationship existed between fledging success and wing chord when all females were analyzed, but especially within the subset of older females (Table 3), indicating that females of extreme wing length (either short or long) tended to fledge the lowest proportion of eggs. Females with small bills also tended to fledge a higher proportion of eggs when individuals of all ages were examined, mainly because of the influence of females that bred for only one year $(r=-0.294, P=0.026, n=57$; for older females, $r=-0.176, P=0.126, n=79)$. In

TABLE 2. Percentage contribution of lifespan (L), proportion of eggs that resulted in fledged young $(\mathrm{P})$, clutch size $(\mathrm{C})$, and tarsus length $(\mathrm{T})$ to lifetime reproductive success of female Eastern Kingbirds in central New York. Data are presented for the sample of females of all ages and separately for older females (lifespan $\geq 2$ years).

\begin{tabular}{|c|c|c|c|c|c|c|c|c|}
\hline \multirow[b]{2}{*}{ Component } & \multicolumn{4}{|c|}{ All females $(n=135)$} & \multicolumn{4}{|c|}{ Older females $(n=78)$} \\
\hline & $\mathrm{L}$ & $\mathrm{P}$ & $\mathrm{C}$ & $\mathrm{T}$ & $\mathrm{L}$ & $\mathrm{P}$ & $\mathrm{C}$ & $\mathrm{T}$ \\
\hline $\mathrm{L}$ & 90.7 & & & & 68.9 & & & \\
\hline $\mathrm{P}$ & -37.0 & 39.2 & & & -20.0 & 45.7 & & \\
\hline C & 3.4 & 0.1 & 3.7 & & 0.4 & -4.6 & 5.5 & \\
\hline $\mathrm{T}$ & 3.4 & -0.2 & -0.2 & 0.2 & 2.7 & -1.2 & -0.6 & 0.3 \\
\hline $\mathrm{L}^{*} \mathrm{P}^{*} \mathrm{C}^{*} \mathrm{~T}$ & -33.9 & & & & -20.4 & & & \\
\hline Overall variance & & & & & & & & \\
\hline
\end{tabular}


TABLE 3. Results of the Poisson (lifespan) or multiple regression (proportion of eggs to yield fledged young and clutch size) analyses of variation of the major components of LRS for female Eastern Kingbirds in central New York.

\begin{tabular}{|c|c|c|c|c|c|c|}
\hline \multirow[b]{2}{*}{ Trait } & \multicolumn{3}{|c|}{ All females $(n=136)$} & \multicolumn{3}{|c|}{ Older females $(n=79)$} \\
\hline & Predictor variable & $\beta^{\mathrm{a}}$ & $P$ & Predictor variable & $\beta^{\mathrm{a}}$ & $P$ \\
\hline \multirow[t]{3}{*}{ Lifespan $^{b}$} & Laying date & -0.029 & 0.025 & Proportion fledge & 2.247 & 0.054 \\
\hline & Proportion fledge & 3.570 & 0.000 & Proportion fledge ${ }^{2}$ & -2.087 & 0.033 \\
\hline & Proportion fledge ${ }^{2}$ & -3.548 & 0.000 & - & & \\
\hline$r^{2}$ & $0.245^{\mathrm{b}}$ & & & $0.085^{b}$ & & \\
\hline \multirow[t]{3}{*}{ Proportion fledge } & Bill length & -0.242 & 0.005 & Wing & 22.50 & 0.005 \\
\hline & Wing & 12.60 & 0.050 & Wing $^{2}$ & -22.56 & 0.005 \\
\hline & Wing $^{2}$ & -12.61 & 0.050 & - & & \\
\hline$r^{2}$ & 0.065 & & & 0.116 & & \\
\hline \multirow[t]{3}{*}{ Clutch size } & Laying date & -0.204 & 0.018 & Laying date & -0.220 & 0.039 \\
\hline & Tarsus length & -0.150 & 0.080 & Tarsus length & -0.360 & 0.002 \\
\hline & - & & & Proportion fledge & -0.322 & 0.015 \\
\hline$r^{2}$ & 0.042 & & & 0.151 & & \\
\hline
\end{tabular}

a Standardized regression coefficient.

${ }^{\mathrm{b}}$ Regression coefficients and $P$ for lifespan based on a Poisson regression, but $R^{2}$ derived from a multiple linear regression based on the variables identified as significant by the Poisson regression.

addition, the proportion of nests lost to predators increased with tarsus length (Spearman's rank correlation: $r=0.200, P=0.018, \mathrm{n}=136$; for older females, $r=0.265, P=0.018, n=79$ ). Mean clutch size of females of all ages declined with breeding date and, after accounting for effects of date, clutch size showed a weak tendency to be larger among females with short tarsi (Table 3). Among older females, clutch size again declined with date, but a strong inverse relationship also existed between clutch size and both tarsus length (Fig. 3) and fledging success (Table 3). Including BrSize5 had only modest effects on one variable. Lifespan correlated positively with BrSize5 (because of the use of older females in the brood-size-enlargement experiments), but the relationships with the other variables (Table 3) all remained qualitatively unchanged.

\section{Discussion}

Intrapopulation variation of lifetime reproductive success. - Observed and simulated LRS of female kingbirds averaged 4 to 5 young, but my estimate of the proportion of females who fledged no young increased from $\sim 11 \%$ in the marked population to $\sim 17 \%$ in the simulated population. On the other hand, the proportion of young contributed by the top $10 \%$ of the most productive adults $(\sim 30 \%)$ and the percentage of adults to raise $50 \%$ of young ( $20 \%$ ) were the same for the observed and simulated populations. The model's realistic description of the statistical distribution of LRS within the real population (Fig. 1) indicated that the model accurately described individual variation of LRS, and that the true percentage of females with zero LRS was likely in the range of $15-20 \%$.

About $20 \%$ of female kingbirds fledged $50 \%$ of all young, a figure that was similar to published results of other species. A relatively low proportion of individuals thus contributed most offspring to the next generation (see also Newton 1989) if fledgling production is a reliable estimate of the number of recruits to the breeding population. I lack data on juvenile survival for kingbirds, but results from many species lend support (see Newton 1989, Weatherhead and Dufour 2000, Brommer et al. 2004, MacColl and Hatchwell 2004).

Correlates of variation of lifetime reproductive success.-Life-long effects of natal conditions are common (Lindström 1999), and the effect of year of hatch-birth on survival prospects, future reproduction, and LRS have become increasingly apparent among birds and mammals (Dhondt 1989, Korpimäki 1992, Rose et al. 1998, Reid et al. 2003; but see Krüger and Lindström 2001, Hansson et al. 2004). Low natal philopatry and the absence of known characters to distinguish second-year from older birds prevented me from testing for true cohort effects. In lieu of 


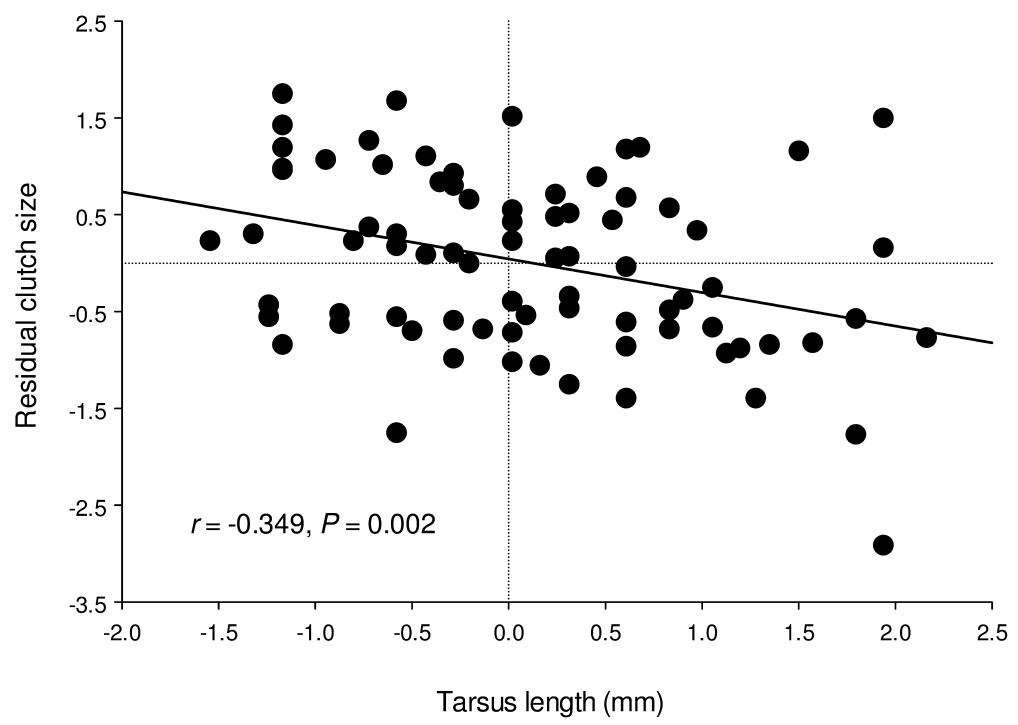

Fig. 3. Residual clutch size of female Eastern Kingbirds (corrected for breeding date and proportion of eggs to yield fledged young; see Table 3) versus tarsus length for females that bred for $\geq 2$ years. Standardized residuals and standardized tarsus length are reported, along with the partial correlation between clutch size and tarsus length $(r=-0.349, P=0.002)$. The simple correlation between clutch size and tarsus length was also significant $(r=-0.276, P=0.014, n=79)$.

a direct test, I tested for and detected an effect of year of entry into the breeding population on LRS, and the pattern appeared to be explained best by variation of lifespan. Deaths of kingbird adults during the breeding season were rare and, therefore, nearly all adult mortality must have occurred either during migration or on the wintering grounds (see also Jones 1986, Sillett and Holmes 2002).

Lifespan is typically the strongest contributor to differences in LRS among long-lived species (reviewed in Clutton-Brock 1988, Newton 1989), and the regression analyses and partitioning of variances of LRS indicated that this was the case for kingbirds, followed by the proportion of eggs laid that yielded fledglings. The contribution of lifespan was especially strong among females of all ages, possibly because of the small range of clutch size in this population $(2-4$, with clutches of 3 comprising $62.5 \%$ of all first clutches) and the unpredictable but frequent loss of nests that appeared to occur without regard to female identity or nesting territory (Murphy 2004). Nest predation accounted for $>70 \%$ of kingbird nest failures, and the substantial effect of nest predation on LRS has undoubtedly shaped nestsite selection (Murphy 1983, Murphy et al. 1997) and much of parental behavior (Blancher and Robertson 1982, Woodard and Murphy 1999).

Depending on the species, LRS has also been shown to vary with phenotypic traits, such as song repertoire (McGregor et al. 1981), habitat quality (Hochachka et al. 1989, Newton 1989), clutch size (Korpimäki 1992), fledging date of young (Visser and Verboven 1999), dispersal behavior (Ekman et al. 1999, Hansson et al. 2004), plumage coloration (Krüger and Lindström 2001), and body size (Bryant 1988, Newton 1989). Kingbird LRS correlated positively with clutch size in all regression analyses, but despite the strong apparent statistical effect $(P \leq 0.009$ in all analyses; Table 1$)$, the partitioning of variances suggested that individual differences in clutch size contributed much less to variation of LRS than either lifespan or fledging success (Table 2). Morphology (i.e., tarsus length) also contributed significantly to the regression model when the one outlier was omitted (Table 1), but the independent effects of morphology on LRS was near zero based on variance partitioning (Table 2).

Lifespan and nest failure thus appeared to swamp potential influences of clutch size and morphology, which begs the question of whether 
the latter traits are meaningless, ecologically and evolutionarily. The answer hinges mainly on the relationship between lifespan and fledging success and other variables. As noted above, virtually all adult mortality must occur away from the breeding grounds, but experiences while breeding may influence the probability of annual survival. Moreover, experimental results indicate that rearing experimentally enlarged broods (five young) carried a survival cost (Murphy 2000). The negative covariance between lifespan and proportion of eggs that resulted in fledglings (Table 2) and the significant polynomial relationship between lifespan and proportion of eggs fledged (shorter lifespan associated with high fledging success; Table 3) are consistent with the experimental findings of a cost of reproduction. Kingbirds spend three to five weeks caring for young after they fledge (Morehouse and Brewer 1968), and the cost of raising two young to independence from an initial clutch of four must inevitably require less energy than if the entire brood fledged. Less energy spent on parental care late in the season may leave an adult better prepared for migration. Covariance between lifespan and tarsus length was low; hence, except for the moderately smaller size of females that bred for only one breeding season, body size appeared to have no relationship to lifespan. Instead, high parental effort (i.e., high proportion of young that fledged) had greater effects on survival prospects. Shorter lifespan of females that fledged few young (Table 3), while seemingly contradictory, has two potential explanations. Dispersal occurs most often after nest failure (Murphy 1996), and permanent emigration may account for the loss of females with low success. Equally likely is the possibility that low-quality females were unable to fledge a high proportion of young and were also more likely to die, independently of their reproductive effort.

At best, body size seemed to factor indirectly into LRS through relationships between (1) fledging success and wing chord, (2) proportion of nests lost to predators and tarsus length, and (3) clutch size and tarsus length. Females of intermediate wing length had the highest fledging success. When the analysis included females of all ages, fledging success was inversely related to bill length. The low fledging success of shortwinged females may, again, reflect female quality, but just as likely, it may represent an age-effect, because wing chord in many species is generally shorter among females in their first potential breeding season (Stutchbury and Robertson 1987, Regosin and Pruett-Jones 2001) and firsttime breeders are often poorer parents than experienced birds (Fowler 1995, Martin 1995). I have no ready explanation for the low fledging success of females with the longest wing chords, except to suggest that it may be a case of stabilizing selection and that long-winged females may represent biologically significant departure from optimal body form (e.g., Jones 1987, Brown and Brown 1998).

The inverse relationship between clutch size and tarsus length of older females, and the direct relationship between proportion of nests lost to predators and tarsus length, also suggest that, generally speaking, large females tended to be less efficient parents. Assuming that tarsus length is a reasonable surrogate for overall body size (Rising and Somers 1989, Senar and Pascual 1997, Nooker et al. 2005), the relationship between clutch size and tarsus length is consistent with Downhower's (1976) hypothesis of an energy-based fecundity cost to large body size. Small females, presumably because of lower daily energy requirements associated with lower total resting metabolic rates (e.g., Burness et al. 1998, Blackmer et al. 2005), may be able to shunt a larger share of energy-nutrients acquired through daily food intake into egg production. The weaker relationship among females of all ages may again represent an influence of age: young females often lay smaller clutches than older females (see above). Earlier breeding date by small females (Murphy 1986a), delayed breeding in years of poor weather (Murphy 1986b, M. T. Murphy unpubl. data), and positive responses of clutch size to food supply (Murphy 1986b) all suggest that energy is limited during the production of first clutches of kingbirds and that even small savings in energy may have positive reproductive consequences.

Nearly all nest failures were attributable to predation, and, presumably as a response to this threat, kingbirds devote much time to nest vigilance (Woodard and Murphy 1999). The proportion of nests lost to predators increased with tarsus length, which again suggests a probable disadvantage of large size. More frequent losses of nests among large birds may have arisen as a result of reduced nest vigilance attributable to the need to devote more time to feed and satisfy energy needs associated with large body size. 
Larger birds may also have been less maneuverable and less successful at defending nests.

Summary._Lifetime reproductive success varied considerably among female kingbirds, and most of the variability was attributable to differences in adult lifespan and the ability of females to rear offspring through the five weeks that eggs-young spend in the nest. Lifetime reproductive success was also positively related to average clutch size, which suggests selection for larger clutches. However, the fact that most initial clutches held only three eggs suggests constraints on egg production. Females that bred for only a single season tended to be smaller than other females but, except for this, LRS was not related directly to size. However, LRS appeared to be indirectly and negatively affected by large female body size, because fledging success declined with increasing wing chord, in part because of an increased proportion of nests lost to predators as size (tarsus length) increased. In addition, large females (long tarsi) produced smaller clutches, which suggests a possible energetic advantage for small females. Hence, although lifespan and the stochastic occurrence of nest predation (Murphy 2004) drove most differences in LRS, it would be inappropriate to conclude that differences in body size were inconsequential. On the whole, the data suggested that large body size carried negative consequences for breeding female kingbirds, and costs associated with large female size may contribute to the existence of sexual size-dimorphism in kingbirds (Murphy 2007).

\section{Acknowledgments}

I thank the many Hartwick College students who assisted on this project, and the many gracious landowners who granted access to their properties. Financial assistance was provided by Trustees Grants from Hartwick College and National Science Foundation (BSR 9106854). Colleagues at Hartwick College, S. Sessions, D. H. Hamilton, and B. Titus, provided much professional encouragement and were (are) great friends. As always, my family (Karmel, Rachel, and Ruth) carried me and served as my touchstone to reality. I am also grateful to two anonymous reviewers and Associate Editor B. K. Sandercock for helpful comments on a previous draft of the manuscript.

\section{Literature Cited}

Blackmer, A. L., R. A. Mauck, J. T. Ackerman, C. E. Huntington, G. A. Nevitt, and J. B. Williams. 2005. Exploring individual quality: Basal metabolic rate and reproductive performance in storm-petrels. Behavioral Ecology 16:906-913.

Blancher, P. J., and R. J. Robertson. 1982. Kingbird aggression: Does it deter predation? Animal Behaviour 30:929-930.

Brommer, J. E., L. Gustafsson, H. Pietiäinen, AND J. Merilä. 2004. Single-generation estimates of individual fitness as proxies for long-term genetic contribution. American Naturalist 163:505-517.

Brown, C. R., AND M. B. Brown. 1998. Intense natural selection on body size and wing and tail asymmetry in Cliff Swallows during severe weather. Evolution 52: 1461-1475.

Brown, D. 1988. Components of lifetime reproductive success. Pages 439-453 in Reproductive Success: Studies of Individual Variation in Contrasting Breeding Systems (T. H. Clutton-Brock, Ed.). University of Chicago Press, Chicago, Illinois.

BRyAnT, D. M. 1988. Lifetime reproductive success of House Martins. Pages 173-188 in Reproductive Success: Studies of Individual Variation in Contrasting Breeding Systems (T. H. Clutton-Brock, Ed.). University of Chicago Press, Chicago, Illinois.

Bryant, D. M., and K. R. Westerterp. 1982. Evidence for individual differences in foraging efficiency amongst breeding birds: A study of House Martins Delichon urbica using the doubly labeled water technique. Ibis 124:187-192.

Bryant, D. M., and K. R. Westerterp. 1983. Time and energy limits to brood size in House Martins (Delichon urbica). Journal of Animal Ecology 52:905-925.

Burness, G. P., R. C. Ydenberg, and P. W. Носнаснка. 1998. Interindividual variability in body composition and resting oxygen consumption rate in breeding Tree Swallows, Tachycineta bicolor. Physiological Zoology 71:247-256.

Butler, R. W. 2000. Stormy seas for some North American songbirds: Are declines related to severe storms during migration? Auk 117: 518-522. 
Clutton-Brock, T. H. 1988. Reproductive Success: Studies of Individual Variation in Contrasting Breeding Systems. University of Chicago Press, Chicago, Illinois.

Coltman, D. W., J. A. Smith, D. R. Bancroft, J. Pilkington, A. D. C. MacColl, T. H. Clutton-Brock, and J. M. Pemberton. 1999. Density-dependent variation in lifetime breeding success and natural and sexual selection in Soay rams. American Naturalist 154:730-746.

Dhondt, A. A. 1989. Blue Tit. Pages 15-33 in Lifetime Reproduction in Birds (I. Newton, Ed.). Academic Press, London.

Downhower, J. F. 1976. Darwin's finches and the evolution of sexual dimorphism in body size. Nature 263:558-563.

Drent, R. H., And S. DAan. 1980. The prudent parent: Energetic adjustments in avian breeding. Ardea 68:225-252.

Ekman, J., A. Bylin, and H. Tegelström. 1999. Increased lifetime reproductive success for Siberian Jay (Perisoreus infaustus) males with delayed dispersal. Proceedings of the Royal Society of London, Series B 266:911-915.

Fowler, G. S. 1995. Stages of age-related reproductive success in birds: Simultaneous effects of age, pair-bond duration and reproductive experience. American Zoologist 35: 318-328.

Freeman, S., And W. M. Jackson. 1990. Univariate metrics are not adequate to measure avian body size. Auk 107:69-74.

Garnett, M. C. 1981. Body size, its heritability, and influence on juvenile survival among Great Tits Parus major. Ibis 123:31-41.

Grafen, A. 1988. On the uses of data on lifetime reproductive success. Pages 454-471 in Reproductive Success: Studies of Individual Variation in Contrasting Breeding Systems (T. H. Clutton-Brock, Ed.). University of Chicago Press, Chicago, Illinois.

Hansson, B., S. Bensch, and D. Hasselquist. 2004. Lifetime fitness of short- and longdistance dispersing Great Reed Warblers. Evolution 58:2546-2557.

HochachKa, W. M., J. N. M. Sмith, AND P. Arcese. 1989. Song Sparrow. Pages 135152 in Lifetime Reproduction in Birds (I. Newton, Ed.). Academic Press, London.

Höткеr, H. 1989. Meadow Pipit. Pages 119-133 in Lifetime Reproduction in Birds (I. Newton, Ed.). Academic Press, London.
JoNEs, G. 1987. Selection against large size in the Sand Martin Riparia riparia during a dramatic population crash. Ibis 129:274-280.

KorpiмäкI, E. 1992. Fluctuating food abundance determines the lifetime reproductive success of male Tengmalm's Owls. Journal of Animal Ecology 61:103-111.

Krüger, O., AND J. Lindström. 2001. Lifetime reproductive success in Common Buzzard, Buteo buteo: From individual variation to population demography. Oikos 93:260-273.

Langston, N. E., S. Freeman, S. Rohwer, and D. Gori. 1990. The evolution of female body size in Red-winged Blackbirds: The effects of timing of breeding, social competition, and reproductive energetics. Evolution 44: 1764-1779.

Lindström, J. 1999. Early development and fitness in birds and mammals. Trends in Ecology and Evolution 14:343-348.

MacColl, A. D. C., And B. J. Hatchwell. 2004. Determinants of lifetime fitness in a cooperative breeder, the Long-tailed Tit Aegithalos caudatus. Journal of Animal Ecology 73: 1137-1148.

Martin, K. 1995. Patterns and mechanisms for age-dependent reproduction and survival in birds. American Zoologist 35:340-348.

Martin, T. E. 1993. Nest predation and nest sites. BioScience 43:523-532.

McGregor, P. K., J. R. Krebs, and C. M. Perrins. 1981. Song repertoires and lifetime reproductive success in the Great Tit (Parus major). American Naturalist 118:149-159.

Mejuer, T., And R. Drent. 1999. Re-examination of the capital and income dichotomy in breeding birds. Ibis 141:399-414.

Morehouse, E. L., And R. Brewer. 1968. Feeding of nestling and fledgling Eastern Kingbirds. Auk 85:44-54.

Murphy, M. T. 1983. Nest success and nesting habits of Eastern Kingbirds and other flycatchers. Condor 85:208-219.

Murphy, M. T. 1986a. Body size and condition, timing of breeding, and aspects of egg production in Eastern Kingbirds. Auk 103: 465-476.

Murphy, M. T. 1986b. Temporal components of reproductive variability in Eastern Kingbirds (Tyrannus tyrannus). Ecology 67:1483-1492.

Murphy, M. T. 1996. Survivorship, breeding dispersal and mate fidelity in Eastern Kingbirds. Condor 98:82-92. 
Murphy, M. T. 2000. Evolution of clutch size in the Eastern Kingbird: Tests of alternative hypotheses. Ecological Monographs 70:1-20.

Murphy, M. T. 2001. Habitat-specific demography of a long-distance, Neotropical migrant bird, the Eastern Kingbird. Ecology 82: 1304-1318.

Murphy, M. T. 2004. Intrapopulation variation in reproduction by female Eastern Kingbirds Tyrannus tyrannus: The impacts of age, individual performance, and breeding site. Journal of Avian Biology 35:252-261.

Murphy, M. T. 2007. A cautionary tale: Cryptic sexual size dimorphism in a socially monogamous passerine. Auk 124:515-525.

Murphy, M. T., C. L. Cummings, and M. S. Palmer. 1997. Comparative analysis of habitat selection, nest site and nest success by Cedar Waxwings (Bombycilla cedrorum) and Eastern Kingbirds (Tyrannus tyrannus). American Midland Naturalist 138:344-356.

Newton, I., Ed. 1989. Lifetime Reproduction in Birds. Academic Press, London.

Nooker, J. K., P.O. Dunn, and L. A. Whittingham. 2005. Effects of food abundance, weather, and female condition on reproduction in Tree Swallows (Tachycineta bicolor). Auk 122: 1225-1238.

Oli, M. K., G. R. Hepp, and R. A. Kennamer. 2002. Fitness components of delayed maturity in female wood ducks. Evolutionary Ecology Research 4:563-576.

Payne, R. B. 1989. Indigo Bunting. Pages 153172 in Lifetime Reproduction in Birds (I. Newton, Ed.). Academic Press, London.

Pettifor, R. A. 1993. Brood-manipulation experiments. I. The number of offspring surviving per nest in Blue Tits (Parus caeruleus). Journal of Animal Ecology 62:131-144.

Price, T. D. 1984. The evolution of sexual size dimorphism in Darwin's finches. American Naturalist 123:500-518.

Regosin, J. V., And S. Pruett-Jones. 2001. Sexual selection and tail-length dimorphism in Scissor-tailed Flycatchers. Auk 118:167-175.

Reid, J. M., E. M. Bignal, S. Bignal, D. I. McCracken, and P. Monoghan. 2003. Environmental variability, life-history covariation and cohort effects in the Red-billed Chough Pyrrhocorax pyrrhocorax. Journal of Animal Ecology 72:36-46.

Ricklefs, R. E. 1969. An analysis of nesting mortality in birds. Smithsonian Contributions to Zoology 9:1-48.

Rising, J. D., AND K. M. Somers. 1989. The measurement of overall body size in birds. Auk 106:666-674.

Rose, K. E., T. H. Clutton-Brock, and F. E. Guinness. 1998. Cohort variation in male survival and lifetime breeding success in red deer. Journal of Animal Ecology 67:979-986.

Senar, J. C., and J. Pascual. 1997. Keel and tarsus length may provide a good predictor of avian body size. Ardea 85:269-274.

Sillett, T. S., AND R. T. Holmes. 2002. Variation in survivorship of a migratory songbird throughout its annual cycle. Journal of Animal Ecology 71:296-308.

Sokal, R. R., and F. J. Rohlf. 1981. Biometry: The Principles and Practice of Statistics in Biological Research, 2nd ed. W. H. Freeman, New York.

Stutchbury, B. J., and R. J. Robertson. 1987. Two methods of sexing adult Tree Swallows before they begin breeding. Journal of Field Ornithology 58:236-242.

Visser, M. E., and N. Verboven. 1999. Longterm fitness effects of fledging date in Great Tits. Oikos 85:445-450.

Weatherhead, P. J., and K. W. Dufour. 2000. Fledging success as an index of recruitment in Red-winged Blackbirds. Auk 117:627-633.

WikLund, C. G. 1995. Nest predation and lifespan: Components of variance in LRS among Merlin females. Ecology 76:1994-1996.

WikLund, C. G. 1996. Breeding lifespan and nest predation determine lifetime production of fledglings by male Merlins Falco columbarius. Proceedings of the Royal Society of London, Series B 263:723-728.

Woodard, J. D., and M. T. Murphy. 1999. Sex roles, parental experience and reproductive success of Eastern Kingbirds, Tyrannus tyrannus. Animal Behaviour 57:105-115.

Associate Editor: B. K. Sandercock 